\title{
Community Participation in Tourism Development Initiatives in Upland Farming Areas: Evidence From Mengeruda Hot Spring Tourism, Flores, Indonesia
}

\author{
$1^{\text {st }}$ Maria Elisabeth Bebhe Bai ${ }^{1}, 2^{\text {nd }}$ Iwan Nugroho ${ }^{2}, 3^{\text {rd }}$ Darmadji $^{3}, 4^{\text {th }}$ Evi Nurifah Julitasari ${ }^{4}$ \\ \{mariaelysabethbebhe@gmail.com ${ }^{1}$, iwanuwg@widyagama.ac.id ${ }^{2}$, darmaji@widyagama.ac.id ${ }^{3}$, \\ nurifah_uwg@yahoo.co.id ${ }^{4}$ \}
}

Department of Agribusiness, Widyagama University of Malang, Indonesia ${ }^{1,2,3,4}$

\begin{abstract}
The natural potential can provide opportunities for tourism-based economic development. This provides an alternative to household businesses that predominantly rely on agriculture. The purpose of this study was to study participation level of local people and formulate strategies for developing Mengeruda hot springs. The survey research was conducted at Mengeruda Village, Soa District, Ngada Regency, East Nusa Tenggara. Interviews were conducted on 40 respondents randomly selected to explore variables of perception, level of participation and local potential of the tourism. The results showed that $55 \%$ of respondents perceived the benefits of the tourism services, although only $30 \%$ of respondents were directly involved. This finding is in line with community participation on the Arnstein's second ladder, or therapy in the nonparticipatory category. The most of the people do not actively respond to economic development opportunities for their welfare.
\end{abstract}

Keywords: Arnstein, farming, Mengeruda, participation, tourism.

\section{Introduction}

Tourism has become one of the prominent industries and is a major sector in the economy of many countries [1]. The role of tourism in economic development is increasingly for Indonesia, indicating service-based capabilities and services of economic sophistication. Tourism development is aimed at affording to local economy diversified by generating a number of tourism-related businesses and economic activities [2]. Furthermore, tourism is not only an economic problem but also a social, cultural, political and other problem, hence tourism is a multi-complex system, with various aspects related and influencing each other. Tourism has become a source of driving community dynamics and is one of the prime movers in socio-cultural change [3].

Indonesia has natural potential, biodiversity, traditional and historical heritage, all of those shape significant resources and capital for tourism development and improvement efforts [4]. Such capital must be used optimally into the implementation of tourism which generally aims to increase national income to improve people's welfare [5].

Local governments in various regions of Indonesia show high initiative in encouraging the development of tourism. Tourism development is a regional backbone sector that is able to compete with other economic activities, especially agriculture. Tourism potential in the region is expected to increase employment, community income, regional economy and foreign 
exchange earnings. The tourism potential in the region will synergize coupled with the life of the agricultural sector, and provide farmers with empowerment experiences for increasing agricultural production and be actively involved in various tourism service activities. The village will develop and prepare their resources to become a tourist destination, and serve tourism services based on the potential of nature, culture and local uniqueness [6]. Tourism activities significantly increase income, studies [7] show that tourism activities increase 1.7 times compared to farming in general. Indonesia shows a more significant competitive than other countries in tourism prices, hence the positive effect of price indicates a marked economic benefit and economic multiplier for the tourism supply chain and the well-being of the people [8].

The development of a tourist village does not markedly change the condition of the village but tends to explore the potential of the village by utilizing the elements found in the village. Local tourism products and services coupled with tourism supporting facilities are tourism attributes in a cycle of tourism activities, to meet a numerous of travel needs. Villagers are capable of carrying out tours services and taking tourists to enjoy the beauty of nature, experiencing life in a village atmosphere with many customs. Tourists can also enjoy farming activities, explore the cultural tradition and the surrounding natural environment provided by the local community [6].

Mengeruda hot spring is one of the natural tourism potentials found in Mengeruda Village, Soa District, Ngada Regency, East Nusa Tenggara. The hot spring location is about $18 \mathrm{~km}$ distance from downtown Bajawa, or an 8-hour road trip from Labuan Bajo. This is one of the main attractions of tourism that invites local or foreign tourists who stop in the middle of their journey to Kelimutu Lake. Data for 2019, the number of foreign and domestic tourists was 12.2 and 82.7 thousand people, respectively. The number of foreign tourists has almost quadrupled in the past four years. Visits in 2020 decreased due to the COVID pandemic [9].

Villagers around the Mengeruda hot springs generally work on upland agriculture. They should be encouraged to take advantage of hot spring tourism to improve the dignity of their livelihood. However, the condition of the community has not involved in supporting tourism, indicating a lack of community participation. Efforts to involve community participation have been done by tourism managers and village governments, but they have not been so far successful. Many factors cause low participation, including education, trust, and transparency [10]. Certain conditions such as lack of funding, low quality of human resources, and incomplete facilities and infrastructure also alienate community involvement [11].

Mengeruda hot spring tourism must be carefully organized to generate local people empowerment, in social, economic, or political aspects [12]. Tourism development is how to direct the achievement to community participation, involvement and empowerment [13]. Participation demonstrates the empowerment of local people in managing tourism as well as encouraging economic activity, environmental conservation and local culture promotion [14]. Empowerment requires all parties to work together to produce productivity, increase individual and community capacity and in the long term. The focus of empowerment is on local people who are socio-economically disadvantaged [15], in which when they succeed in elevating their economy, it becomes an indication that empowerment and participation have functioned properly.

Community participation provides people with an opportunity to increase the income and welfare of those who mostly work in agricultural businesses. Therefore, researching community participation in the development of the Mengeruda hot spring tourism object is urgently required, while studies focus on the condition of rural tourism in general. The purpose of this study was to evaluate the participation of upland farming communities in 
managing tourism objects and to determine the development strategy for managing Mengeruda hot springs.

\section{Research Method}

This research was conducted in Mengeruda Village, Soa District, Ngada Regency, East Nusa Tenggara Province, Indonesia. The study used a descriptive and quantitative approach by surveying people around hot spring sites. The study selected 40 respondents who were selected randomly from the community residing adjacent the tourism site. Interviews were conducted to explore individual data, respondents' knowledge and perceptions of Mengeruda tourist attractions, and participation in hot spring tourism activities. The study also interviewed five community leaders such as youth, community leaders, village heads to see their views on developing tourism.

The analytical method includes a series of three steps. First, descriptive analysis to find a depiction of participation from seven questions questionnaire that represent cognitive, affective and psikomotoric aspects of participation. Question statement ranges from respondents' knowledge to behavior regarding the existence of tourist attractions. Close ended question submitted to 40 respondents in yes or no. Descriptive analysis was performed by tabulating and measuring the difference in responses using chi-square.

Table 1. Eight Rungs on a ladder of citizen participation.

\begin{tabular}{cll}
\hline Rung & Citizen Participation & Category \\
\hline 8 & Citizen control & Degree of citizen power \\
7 & Delegated power & \\
6 & Partnership & \\
\hline 5 & Placation & Degree of tokenism \\
4 & Consultation & \\
3 & Informing & Non participation \\
\hline 2 & Therapy & \\
1 & Manipulation &
\end{tabular}

Source: [16]

Second, measuring participation is based on Arnstein's ladder of participation [16]. Questionnaire questions were submitted to obtain respondents' reactions, the extent of their response to what has been done by the government to develop tourist attractions. The concept of Arnstein's ladder of participation (Table 1) was adopted by compiling the eight questions according to the level of community participation in the development of hot spring tourism. Five community leaders as respondents give answers in an ordinal scale: strongly disagree (1) to strongly agree (5). The determination of the level of participation ladder $(\mathrm{R})$ is calculated by the following formula:

$$
\mathrm{R}=\sum(\mathrm{p} \times \mathrm{a})
$$

In which $\mathrm{p}$ is the number of respondents who chose the answer, and a value of answers strongly disagreed (1), disagreed (2), neutral (3), agreed (4) and strongly agreed (5). From this calculation, eight $\mathrm{R}$ values will be found. The highest $\mathrm{R}$ number reflects the participation 
ladder category. This study attempts to demonstrate a new approach to calculating the participation ladder.

Third, the SWOT analysis method (Strength, Weakness, Opportunity and Threat, SWOT). The method prepares a total of sixteen questionnaire questions, or four questions on each SWOT component. The analysis is done by tabulating respondents' answers, assigning importance weights and calculating scores for each SWOT component. Tourism development strategy refers to the calculation of the difference in scores $\mathrm{S}$ minus $\mathrm{W}$ and $\mathrm{O}$ minus $\mathrm{P}$. Thus, the strategy is determined based on the SWOT component which displays the highest score of external and internal factor.

\section{Result and Discussion}

\subsection{Geographical and Demographic Description}

Mengeruda hot water tourism is one of the tourist objects located in Mengeruda Village, Soa District, Ngada Regency, East Nusa Tenggara Province, Indonesia. The geographical location is $8^{\circ} 42^{\prime} 30.5^{\prime \prime} \mathrm{S} 121^{\circ} 05^{\prime} 12.5^{\prime \prime} \mathrm{E}$ (Figure 1). The tourist area has an area of \pm 2 ha of the total area of Mengeruda Village $2.75 \mathrm{~km}^{2}$. The Mengeruda hot spring is located on a plain with an altitude of $330 \mathrm{~m}$ above sea level. Air temperatures ranging from 25-30 C and rainfall $1500-2000 \mathrm{~mm}$ per year [9][17].

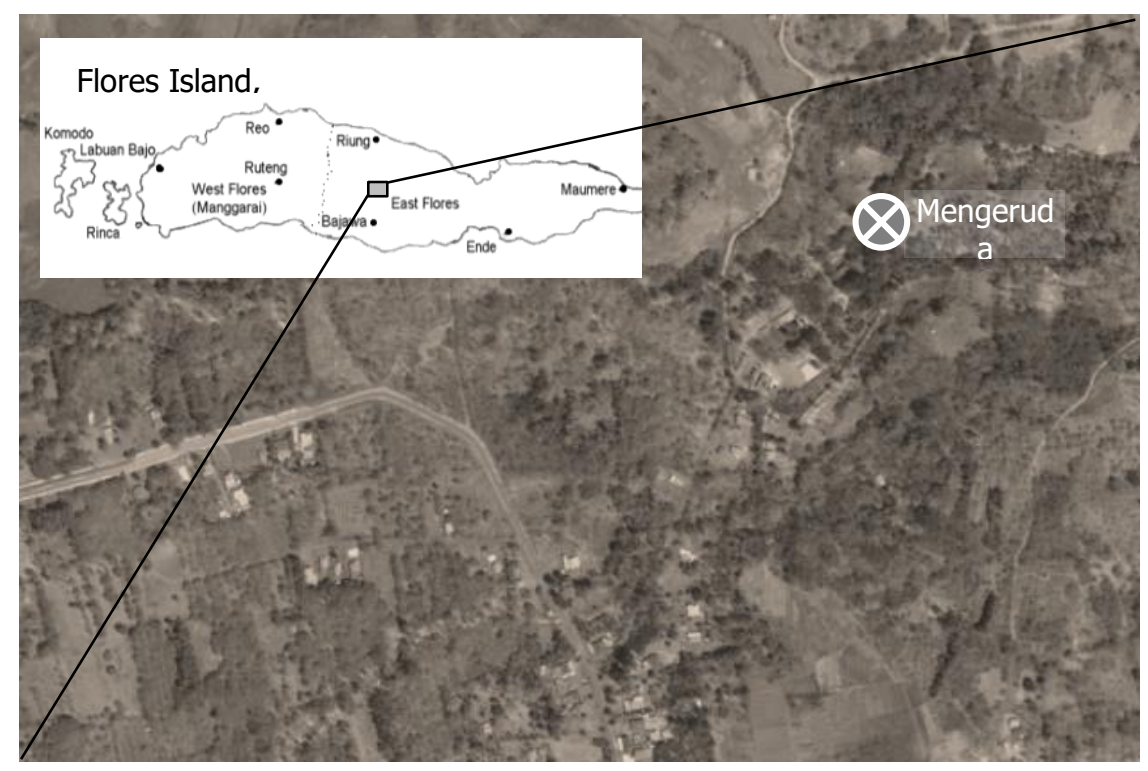

Fig. 1. Map of Mengeruda village (googlemap). 
The springs for this bath come from Mount Inielika in Bajawa. The hot water here is known to have properties that can cure various diseases, the temperature of the hot water and the content of certain volcanic minerals can be a medium for treatment and health therapy. The baths are in the form of pools with different temperature levels ranging from 44 to 36 degrees Celsius. The content of sulfur and other volcanic substances originating from the earth's magma that makes hot water also provides healthy properties. In the rainy season, the hot water flows like a very heavy rapid, while during the dry season the volume of water flow decreases and causes the pool to dry up.

Mengeruda Village has a population of 1,238 people with 257 households [17]. $94 \%$ of the population aged over 10 work in the agricultural sector. Agricultural upland in the form of rainfed, dryland and yards, planted mainly for rice, corn, cassava and sweet potatoes. Rainfed and dryland farming is a very dominant land use in Mengeruda Village or in Soa district in general. Ngada district's GRDP per capita in 2019 was 20 million rupiahs, equivalent to US\$1,380 [9]. Socio-economic life is relatively low although not in a subsistence economy category.

Mengeruda Village is $25 \mathrm{~km}$ distance from Bajawa City, the capital of Ngada Regency. This location can be accessed by road transportation with adequate infrastructure quality. The location has a very strategic position, only $2 \mathrm{~km}$ distance from Turelelo Soa airport (Bajawa Soa Airport). The Mengeruda tourist site established in 1997 and the attraction has grown until now. This tourist spot also provides various facilities such as toilets, restaurants, campsites, forests with trails (see https://www.youtube.com/watch?v=tOcs1Ue7mF8). Tour operators offer Mengeruda hot spring tours in package trips to Kelimutu lake tourist destinations, making them increasingly known by people from out of town and overseas.

In 2019, the number of tourists visiting Mengeruda hot springs reached 94,872 people. In 2020, tourist visits decreased due to the COVID pandemic. The number of foreign tourists in 2019 was 12,202 people, an increase of almost four times in four years (Table 2).

Table 2. Number of visits to Mengeruda hot spring tourism, 2016-2020.

\begin{tabular}{|c|c|c|c|c|c|}
\hline Tourist origin & 2016 & 2017 & 2018 & 2019 & 2020 \\
\hline & & & people & & \\
\hline Foreign & 3,498 & 2,347 & 7,342 & 12,202 & 191 \\
\hline Domestic & 50,358 & 51,154 & 81,715 & 82,670 & 20,884 \\
\hline Total & 53,856 & 53,501 & 89,057 & 94,872 & 21,075 \\
\hline
\end{tabular}

Source: [9]

\subsection{Respondent Characteristics}

This study showed that $45 \%$ of respondents were aged 31 to 40 years, and $37.5 \%$ were aged 41 to 50 years. Most of the farmers have completed elementary education (45\%) and junior high school $(22.5 \%)$. Most of the respondents are farmers, working on an area of 1-2.5 ha $(47.5 \%)$ and less than 0.5 ha $(37.5 \%)$. They cultivate rice and maize $(50 \%)$. Farmers receive crops with an income per planting season of 5-10 million rupiahs $(52.5 \%)$ and 1-5 million rupiahs $(37.5 \%)$. $55 \%$ of respondents do not have a job other than farming, while $37.5 \%$ have a side job as a trader (Table 3 ).

The general character indicates that the respondents depend on upland agriculture, with relatively low social economic conditions. With the condition of small size land owned, the results of agricultural production (rice or corn) are not optimal to provide adequate net 
income. Farmers who rely only on the agricultural sector, affording the lives of those who are not prosperous or in poor condition. Therefore, encouraging the participation of farmers in the Mengeruda hot spring tourism service is a wise choice that can guarantee the welfare and livelihood of the farmers.

Table 3. Characteristic of respondents.

\begin{tabular}{|c|c|c|c|c|c|}
\hline Variable & People & Proportion & Variable & People & Proportion \\
\hline & & $\%$ & & & $\%$ \\
\hline Sex & & & Age & & \\
\hline Male & 20 & 50.0 & $20-30$ years & 6 & 15.0 \\
\hline Female & 20 & 50.0 & $31-40$ years & 18 & 45.0 \\
\hline Cultivated crops & & & $41-50$ years & 15 & 37.5 \\
\hline Rice & 10 & 25.0 & $51-60$ years & 1 & 2.5 \\
\hline Rice+corn & 20 & 50.0 & Education level & & \\
\hline Rice+corn+guava & 10 & 25.0 & Elementary school & 16 & 45.0 \\
\hline Land size & & & Junior High School & 9 & 22.5 \\
\hline $0.0-0.5$ ha & 15 & 37.5 & Senior High School & 8 & 20.0 \\
\hline $0.5-1.0$ ha & 6 & 15.0 & University & 5 & 12.5 \\
\hline $1.0-2.5$ ha & 19 & 47.5 & Side occupation & & \\
\hline The income per planting & $\operatorname{ason}^{1}$ & & Gate keeper & 2 & 5.0 \\
\hline 1.0-5.0 millions IDR & 15 & 37.5 & Trader & 15 & 37.5 \\
\hline 5.0-10.0 millions IDR & 21 & 52.5 & Teacher & 1 & 2.5 \\
\hline 10.0-15.0 millions IDR & 4 & 10.0 & None & 22 & 55.0 \\
\hline
\end{tabular}

${ }^{1}$ one planting season equals to three months; 1 US\$ equals to 14,500 IDR

Efforts to develop tourism in the socio-economic conditions of deprived communities are not an easy matter. The inhibiting factors are always complicated, usually deal with limitations in financing, the quality of human resources, facilities or infrastructure, and knowledge about tourism. The steps to finding solutions may be long-term work, and require consistency and commitment measures, including tourism dissemination, providing skills training, fostering tourism villages, participating in marketing and promotion [11].

\subsection{Community Participation}

A description of the respondent for showing participation is presented in Table 4, in which respondents indicated a significant difference in answers among the seven questions. All respondents (100\%) are aware of the existence of Mengeruda hot spring tourism, and they perceive that hot spring tourism provides a benefit (55\%) and improves welfare (55\%). This is also in line with their wish to be more involved in tourism activities (55\%), and are willing to attend training and learn to operate tourism activities (50\%). Overall, the participation responses to questions 1 to 5 are typical cognitive and affective statements. In other words, this indicates a positive attitude of respondents towards the existence of Mengeruda hot spring tourism, with levels above $50 \%$.

However, when respondents answering questions 6 and 7 which indicates behavioral or psychomotor statements, they showed relatively low in yes answering. Indeed, it was only $12.5 \%$ of respondents stated that they had been involved in management, and 30\% worked in activities as traders, janitors, and gate keeper. This response indicates that the level of participation in the Mengeruda hot spring tourism activity is relatively low, in which they were more likely as supporting workers with the unskilled assignment. 
Table 4. Respondents participation in Management of Mengeruda hot spring tourism.

\begin{tabular}{llrr}
\hline No & Question Statement & \multicolumn{2}{c}{ Answering Yes } \\
\hline & & people & $\%$ \\
1 & Do you know about Mengeruda hot spring tourism? & 40 & 100.0 \\
2 & Does the existence of tourism provide benefits to your life? & 22 & 55.0 \\
3 & Can the existence of tourism improve the welfare of the community? & 22 & 55.0 \\
4 & Do you want to be involved in Mengeruda hot spring tourism activities? & 22 & 55.0 \\
5 & Are you willing to participate in training and learning in tourism activities? & 20 & 50.0 \\
6 & Have you been involved in the management of tourism activities? & 5 & 12.5 \\
7 & Do you work as a trader, janitor, gate keeper and others? & 12 & 30.0 \\
\hline
\end{tabular}
Kruskal Wallis Test: Chi-Square 69.754, degree of freedom 6, p value 0.000

Table 5 further shows participation level using the eight rungs of the Arnstein ladder. This approach complements the findings of Table 4, by considering the extent to which community participation responds to efforts by the government to develop Mengeruda hot springs. Respondents have understood that the government worked to assist tourism development initiatives, although the majority of respondents showed disagree or strongly disagree responses. Statistically, respondents showed a significant difference in answers among the eight questions asked. The downward direction of the line (1 to 8) indicates that the participation ladder is getting higher. This reflects the higher community empowerment in responding to tourism development programs, hence the community has the power to ensure the benefits of tourism flow to them coupled with duties and responsibilities.

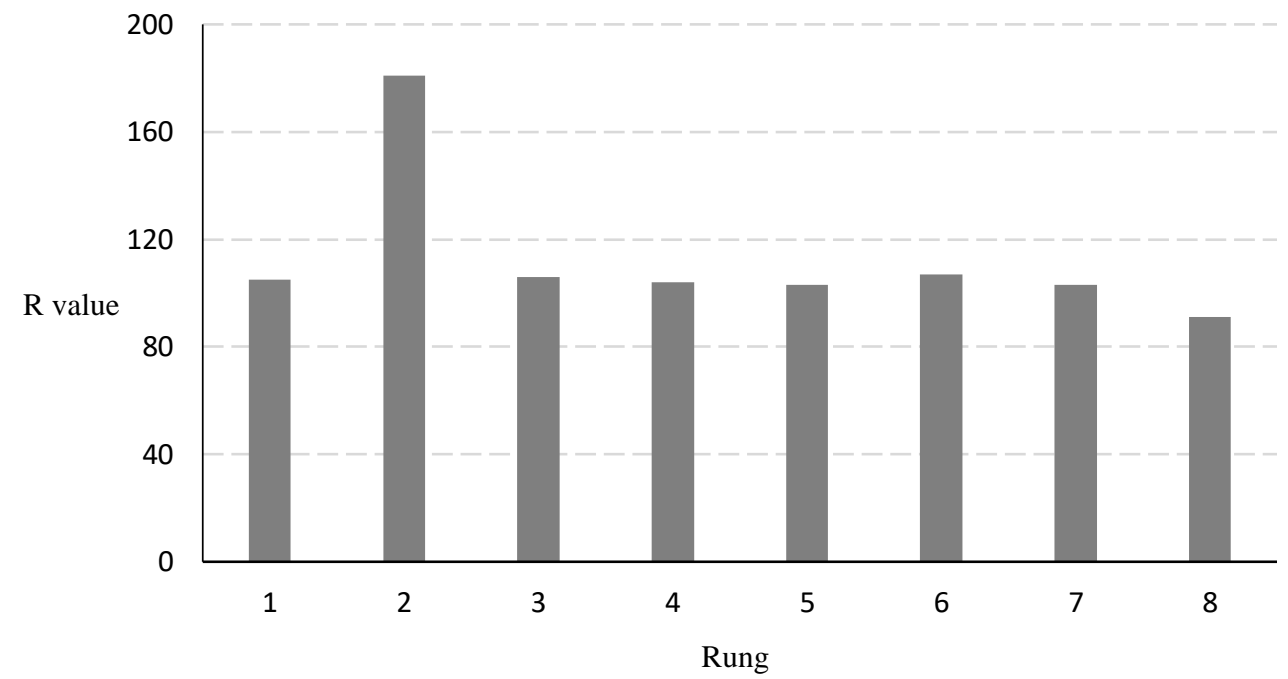

Fig. 2. Participation Ladder of Mengeruda hot springs tourism.

Table 5 shows that the highest value is the second ladder $(\mathrm{R}=181)$. The sequence of changes in the value of $\mathrm{R}$ is ladder 1 (105) going up to ladder 2 (108), and then decreasing thereafter (less 120). The lowest $\mathrm{R}$ value is found on ladder 8 (91) (Figure 2). These findings indicate that the level of respondent's participation in therapy positions, or not participatory. In 
this condition, the government has worked to deliver a work program (perhaps a vision and mission) to improve hot spring tourism to the community or the representatives, but the community demonstrates an attitude of only listening or passive. Research [18] found the level of community participation on the first ladder of non-participation and the second ladder of tokenism in Ciliwung river tourism in the city of Depok. Study [19] in Sebubus Village, Tanjung Belimbing Nature Tourism Park also found the level of participation consultation.

Table 5. Arnstein participation ladder on hot springs tourism management.

\begin{tabular}{|c|c|c|c|c|c|c|c|}
\hline No & Question Statement & $\begin{array}{l}\mathrm{SD} \\
(=1)\end{array}$ & $\begin{array}{c}\mathrm{D} \\
(=2)\end{array}$ & $\begin{array}{c}\mathrm{N} \\
(=3)\end{array}$ & $\begin{array}{c}\text { A } \\
(=4)\end{array}$ & $\begin{array}{l}\text { SA } \\
(=5)\end{array}$ & $\begin{array}{c}\mathrm{R} \\
\text { value }\end{array}$ \\
\hline 1 & $\begin{array}{l}\text { You attended a meeting activity for the development of } \\
\text { Mengeruda hot spring tourism }\end{array}$ & 7 & 17 & 4 & 8 & 4 & 105 \\
\hline 2 & $\begin{array}{l}\text { Meetings related to the development of hot spring tourism } \\
\text { has been carried out by the government }\end{array}$ & 1 & 0 & 0 & 15 & 24 & 181 \\
\hline 3 & $\begin{array}{l}\text { You regularly express ideas or opinions in meetings related } \\
\text { to the development of hot spring tourism }\end{array}$ & 5 & 17 & 7 & 9 & 2 & 106 \\
\hline 4 & $\begin{array}{l}\text { Your opinion is well received by the village government or } \\
\text { tourism manager }\end{array}$ & 2 & 23 & 7 & 5 & 3 & 104 \\
\hline 5 & $\begin{array}{l}\text { You are actively involved in the deliberations on the } \\
\text { development plan for the hot spring tourism area }\end{array}$ & 7 & 17 & 6 & 6 & 4 & 103 \\
\hline 6 & $\begin{array}{l}\text { You are assigned to carry out the management of the } \\
\text { Mengeruda hot spring tourist area }\end{array}$ & 3 & 20 & 5 & 11 & 1 & 107 \\
\hline 7 & $\begin{array}{l}\text { You are involved in decision making in managing the } \\
\text { Mengeruda hot springs area. }\end{array}$ & 2 & 24 & 3 & 11 & 0 & 103 \\
\hline 8 & $\begin{array}{l}\text { You are fully involved in managing the Mengeruda hot } \\
\text { spring area, for example controlling organizational, HR, or } \\
\text { financial management. }\end{array}$ & 15 & 11 & 4 & 8 & 2 & 91 \\
\hline
\end{tabular}

The low-level participation, according to [20] is caused by the lack of transparent information received by the community, this then induces the community to lack access to development control. Mak et al., [21] found a low level of actual participation in public consultations (Arnstein's fourth ladder of participation). Lack of awareness and inappropriate schedule of activities are the two main reasons for low attendance in tourism development activities in Tai $\mathrm{O}$, Hongkong. In such cases, to encourage community participation, it is required empowerment and technical assistance [10][22].

According to [16], the ladder of community participation in the second rung allows the government or decision maker to "educate" or "cure" people first so that they then afford to participate in the planning or implementing programs. According to [23], Arnstein's approach is useful for building awareness of the participation of deprived community groups in the planning stage. This confirms the findings of Table 4, in which the community require empowerment through training programs and increased motivation so that community participation increases to exceed current conditions, as janitors or gate keepers.

Quantitative approach of this study seems to provide a fairly good estimate. With the calculation as equation 1, where the respondent's answer is multiplied by the weighting of the Likert scale, it allows more sensitive results to estimate the ladder of participation. The calculations from this study can be an alternative to a qualitative descriptive approach [24] which calculates the frequency of respondents' responses. 


\subsection{Tourism Development Strategy}

This study also see a tourism development strategy using a SWOT approach. The research design emphasizes the socio-economic conditions of the community to build community participation in Mengeruda hot spring tourism services. Table 6 shows that the strength of natural beauty and tourism management is getting better. Meanwhile, the weakness is that the people indicate strongly an agrarian character and the tourism management organization has not functioned optimally. Opportunities for tourism management (Table 7) are shown by the increasing number of visits and the role of local governments in supporting tourism, on the other hand, the threat is indicated by environmental damage and competition for economic gains as a result of tourism development initiatives.

Table 6. SWOT Analysis of internal factors.

\begin{tabular}{lcrr}
\hline Internal factors Statement & Weight & Rating & Score \\
\hline Strength & & & \\
1. The beauty of Mengeruda hot spring is widely known & 0.125 & 9 & 1.13 \\
2. Mengeruda hot spring tourism affords to improve people's welfare & 0.093 & 8 & 0.74 \\
3. People are highly motivated to engage in tourism & 0.125 & 8 & 1.00 \\
4. Management of the will get more developed in the future & 0.125 & 9 & 1.13 \\
$\quad$ Total (S) & & & 3.99 \\
\hline $\begin{array}{l}\text { Weakness } \\
\text { 1. The tourism management organization does not function optimally }\end{array}$ & 0.125 & 7 & 0.88 \\
2. Road infrastructure, water supply, stalls, parking area are not adequate & 0.125 & 7 & 0.88 \\
3. The people is highly dependent remaining on agriculture & 0.156 & 9 & 1.40 \\
4. People have no experience to involve in hot spring tourism & 0.125 & 5 & 0.63 \\
$\quad$ Total (W) & & & 3.78 \\
\hline (S-W) & & & +0.22 \\
\hline Ratings range from 1-10; 5 is the midpoint (moderate) & &
\end{tabular}

Table 7. SWOT Analysis of external factors.

\begin{tabular}{lrrr}
\hline External Factors Statement & Weight & Rating & Score \\
\hline Opportunity & 0.160 & 9 & 1.44 \\
1. The number of tourist visits is increasing & 0.160 & 9 & 1.44 \\
2. Local government plans to help tourism development initiatives & 0.120 & 7 & 0.84 \\
3. The number of stalls or traders is getting more and more coming & 0.120 & 5 & 0.60 \\
4. People from outside the village also receive benefits from tourism & & & 4.32 \\
$\quad$ Total (O) & & & \\
Threat & 0.120 & 7 & 0.84 \\
1. Threat of environmental damage or landslides & 0.080 & 4 & 0.32 \\
2. Crime or security disturbances increase & 0.080 & 4 & 0.32 \\
3. Conflicts of interest can occur in tourism management & 0.160 & 7 & 1.12 \\
4. Competition will threaten the income of working people & & & 2.60 \\
$\quad$ Total (T) & & +1.72 \\
\hline (O-T) & &
\end{tabular}

Ratings range from 1-10; 5 is the midpoint (moderate)

The calculation of the SWOT analysis produces a total internal score of +0.22 , which is the difference between strengths minus weaknesses $(\mathrm{S}-\mathrm{W})$. Meanwhile, the external score shows the difference between opportunities and threats $(\mathrm{O}-\mathrm{T})$ of +1.72 . This calculation places the development strategy with a strength-opportunity (S-O) focus. This strategy is carried out 
with a focus on elements of internal strengths to take advantage of external opportunities as optimally as possible. These efforts related to community participation include:

1. Develop tourism organizations, expand products and services of tourism business and establish local leadership to ensure better tourism governance, community involvement and improvement of community welfare

2. Promote the natural beauty and landscape of Mangeruda so that it is known to more widely tourists. This requires promotional support using social media, as well as government support in providing infrastructure and facilities to destination sites

3. Develop tourism entrepreneurship empowerment programs by optimizing the role of government coordination involving interested parties

4. Conduct motivation and skills programs so that more people participate in tourism businesses.

This research confirms studies [25][26], who found an S-O strategy by focusing on tourism promotion, organizational strengthening, infrastructure provision and product or tourism development. Meanwhile [27] focuses on investor involvement, human resources training, promotion, and expansion of agro-tourism production. The S-O strategy typically contains aggressive steps, where business conditions are usually growing fast in a favorable atmosphere, accompanied by full support from other parties couple with external conditions can be controlled. This is in accordance with the condition of Mengeruda hot spring tourism, in which community participation is immediately required. Community participation is shaped by elements of understanding the planning process, representativeness of participants, and a substantial degree of political involvedness [28]

\subsection{Research Implications}

This study also see a tourism development strategy using a SWOT approach. The research design emphasizes the socio-economic conditions of the community to build community participation in Mengeruda hot spring tourism services. Table 6 shows that the strength of natural beauty and tourism management is getting better. Meanwhile, the weakness is that the people indicate strongly an agrarian character and the tourism management organization has not functioned optimally. Opportunities for tourism management (Table 7) are shown by the increasing number of visits and the role of local governments in supporting tourism, on the other hand, the threat is indicated by environmental damage and competition for economic gains as a result of tourism development initiatives.

Build local leadership. Low participation is generally due to low levels of trust, in which this usually causes various problems and sources of conflict that affect tourism development initiatives [22]. This is also related to the lack of education, transparency, hence causing people to be alienated from the development process [10]. The issue of ordinary leadership is a crucial key, and afford a way out to address such disadvantage situations. Communities require inclusive leadership, which is trusted and able to bring about change, especially in the world of tourism [29][30]. Once trust is built, community participation moves responsively following the influence of leadership with entrepreneurial and innovative characteristics [7]. Especially in the current COVID-19 pandemic, where the tourism economy is declining [31], leaders are required to have solidarity and empathy personality [32][33] who taking innovative steps and partisanship [34] to help people or families who are impacted by the pandemic.

The community should be encouraged to initiate co-creation through an empowerment process. People are required to involve together in initiating, designing and implementing 
work plans [23][35]. On the other hand, the government becomes the facilitator of the collaboration process and coordinates other interested parties, such as NGOs, banks, or other support facilities. Collaborative requires include increasing social capacity, financing, infrastructure development, institutional development and marketing [18]. The social capacity of tourism development is encouraged to continue to involve the community not only in the planning aspect, but how they collaborate in carrying out networking, monitoring, evaluation, and innovation functions [35]. This collaboration will accelerate the achievement of tourism development goals and generate welfare benefits for people.

The development of Mengeruda hot spring tourism needs to stimulate tourism potential in the surrounding area. The concept of the Flores Destination Management Organization (DMO) can be a guide for empowering tourist destination objects and improving community skills. The trend of Flores overland tourism from Labuan Bajo to Ende and vice versa has provided an opportunity for Ngada Regency to be visited by more tourists. Around the Mengeruda hot springs, you will find archaeological museums at the Matamenge site, Piga hot springs, 17 islands marine parks, Ogi waterfalls, Wawomudha lakes, or cultural tours of traditional villages [9]. All tourism destinations need to be jointly empowered. More tourism empowerment activities, it will accelerate the transformation from addiction in the agricultural sector. As a result, this will increase community participation in development and improve their welfare.

Young generation involvement. Promoting Mengeruda hot spring tourism or other tourism destination in Ngada regency needs to involve the participation of the younger generation through the use of social media. Gadget technology has become a part of the lifestyle of the younger generation and can be used to share and promote tourism objects [36][37] by writing their tourism experiences and activities [38]. Photos about the natural beauty of Ngada regency can build a positive image, generate motivation to visit [39], and send messages about environmental and cultural conservation [40].

\section{Conclusion}

This study shows that the level of participation in the Mengeruda hot spring tourism activity is relatively low, and the community still relies on upland farming for their livelihood. The research found that 55\% of respondents stated that the existence of Mengeruda hot spring tourism provided benefits and increased welfare. However, only $12.5 \%$ of respondents had been involved in management, and 30\% worked in activities as traders, janitors, and gate keepers.

Arnstein's participation ladder calculation quantitatively involving Likert scale weighting can work satisfactorily and can be an alternative to a qualitative descriptive approach that calculates the frequency of respondents' responses. This study found the ladder of participation at level 2 in the therapy position, or not participatory. By doing so, this requires steps to educate and learn through training programs to increase community participation. Furthermore, the development of Mengeruda hot spring tourism based on increasing participation needs to focus on the measures of developing tourism promotion, developing tourism organizations and businesses, empowering entrepreneurship, and increasing community motivation and skills in tourism businesses.

This research provides fundamental implications for increasing community participation. First, building local leadership to suppress the problem of low trust and information gaps that 
cause low participation. Second, developing co-creation to ensure the empowerment process runs well. Third, integrating tourism activities within the framework of the Flores Destination Management Organization (DMO) activities. Fourth, involving the younger generation promoting Mengeruda hot spring tourism through the use of social media.

\section{References}

[1] WTTC. Regional Overview 2019. World Travel \& Tourism Council (WTTC). Available https://wttc.org/Portals/0/Images/EIR2019-Infographic-Map-Regional.png?ver=2021-04-06170730-000 (accessed Jul. 24, 2021).

[2] Mak BKL. Community participation in tourism: a case study from Tai O, Hong Kong. The University of Hong Kong; 2011.

[3] Nugroho I, Rahayu YI. Hospitality, Suatu Industri Strategis. Isu-isu Spesial Manajemen Strategik, 1st ed., A. R. Wardhani, Ed. Malang: Intelegensia Media. 2019; pp. 249-263.

[4] Government of Indonesia, "Law No 102009 about Tourism," Jakarta, 10, 2009. [Online]. Available: https://www.kemenparekraf.go.id/asset_admin/assets/uploads/media/old_file/4636_1364UUTentangKepariwisataannet1.pdf. [Accessed: Jul. 24, 202].

[5] Butarbutar R, Soemarno R. Environmental Effects Of Ecotourism In Indonesia. J. Indones. Tour. Dev. Stud. 2013; 1(3): 97-107.

[6] Nugroho I, Negara PD. Pengembangan Desa Melalui : Dilengkapi dengan peraturan perundangan tentang pedoman pengembangan desa wisata. Solo: Era Adicitra Intermedia; 2015.

[7] Purnomowati W, Nugroho I, Negara PD. Entrepreneurship Ability On Ecotourism Services of Local People in Bromo Tengger Semeru National Park, Malang Regency, East Java, Indonesia. 11th International Entrepreneurship Forum (11th IEF) Conference Entrepreneurship and Sustainability: From Lifestyles to Innovative Enterprises in Creative and Sustainable Environments. 2012; 3-6: 458-473.

[8] Muryani MF, Permatasari, Esquivias MA. Determinants of tourism demand in Indonesia: A panel data analysis. Tour. Anal. 2020; 25(1); 77-89.

[9] Ngada Regency. Midterm Development Planning (RPJMD) 2021-2024. BP-Litbang Ngada, Ngada, [Online]. Available: https://portal.ngadakab.go.id/rancangan-technokratik-rpjmd-kabupaten-ngadatahun-2021-2024/. [Accessed: Jul. 20, 2021]

[10] Adebayo AD, Butcher J. Constraints and Drivers of Community Participation and Empowerment in Tourism Planning and Development in Nigeria. Tour. Rev. Int. 2021; 25(2):209-227.

[11] Safii AA, Pujiati A. Community Participation Level in Development of Keseneng Tourism Village. Effic. Indones. J. Dev. Econ. 2019; 2(2): 376-386.

[12] Scheyvens R. Ecotourism and the empowerment of local communities. Tour. Manag. 1999; 20: 245-249.

[13] Kumar R, Gill SS, Kunasekaran P. Tourism as a Poverty Eradication Tool for Rural Areas in Selangor, Malaysia. Glob. J. Hum. Soc. Sci. 2012; 12(7):21-26.

[14] Ramón-Hidalgo AE, Harris LM. Social Capital, political empowerment and social difference: a mixed-methods study of an ecotourism project in the rural Volta region of Ghana. J. Sustain. Tour., 2018; 26(12):2153-2172.

[15] Sukserm T, Thiengkamo N, Thiengkamol T. Development of the ecotounsm management model for forest park. Soc. Sci. 2012; 7(1): 95-99.

[16] Arnstein SR. A Ladder Of Citizen Participation. J. Am. Plan. Assoc. 1969; 35 (4): 216-224.

[17] BPS Ngada Regency. Soa District in Figure 2020. [Online]. Available: https://ngadakab.bps.go.id/publication/2020/09/28/9eb63e910d60bb3a5557846f/kecamatan-soadalam-angka-2020.html. [Accessed: Jul. 20, 2021]

[18] Kurniasari E, Rustiadi E, Tonny F. Strategi Pengembangan Ekowisata Melalui Peningkatan Partisipasi Masyarakat, Studi Kasus Komunitas Kelurahan Kalimulya Kota Depok. J. Manaj. Pembang. Drh. 2019; 5(2). 
[19] Elisca E, Idham M, I. A. M. Partisipasi Masyarakat Dalam Pengembangan Ekowisata Pada Kawasan Taman Wisata Alam Tanjung Belimbing Kecamatan Paloh Kabupaten Sambas. J. Hutan Lestari. 2020; 8(3).

[20] Hashim H, Regina GA. Penglibatan Komuniti dalam Program Pembangunan Luar Bandar: Kajian Kes di Pusat Pertumbuhan Desa Gedong, Sarawak. Akademika. 2009; 77:41-67, 2009.

[21] Mak BKL, Cheung LTO, Hui DLH. Community participation in the decision-making process for sustainable tourism development in rural areas of Hong Kong, China. Sustain; 2017;. 9 (10).

[22] Setokoe TJ, Ramukumba T. Challenges of community participation in community-based tourism in rural areas. WIT Trans. Ecol. Environ. 2020; 248: 13-22.

[23] Lund DH. Co-Creation in Urban Governance: From Inclusion to Innovation. Scand. J. Public Adm., 2018; 22(2):3-17.

[24] Permatasari C, Soemirat J, Ainun S. Identifikasi Tingkat Partisipasi Masyarakat dalam Pengelolaan Air Bersih di Kelurahan Cihaurgeulis. Reka Lingkung. 2018; 1 (6):1-10.

[25] Maulidiya L, Hayati M. Potensi dan Strategi Pengembangan Pariwisata di Pulau Mandangin Kabupaten Sampang. AGRISCIENCE. 2020; 1 (2): 507-529.

[26] Kuswandari M, Hariani D. Strategi Pengembangan Kepariwisataan di Dinas Kebudayaan dan Pariwisata Kabupeten Boyolali. J. Public Policy Manag. 2012;. 1(2): 71-80.

[27] M. A. Fadlil, W. Sumekar, and D. Mardiningsih, "Strategi Pengembangan Agrowisata Berbasis Bunga Krisan (Chrysanthemum morifolium R.) di Taman Bunga Celosia, Desa Candi Kecamatan Bandungan Kabupaten Semarang,” Ekon. Pertan. dan Agribisnis, vol. 4, no. 1, pp. 39-50, 2020, doi: 10.21776/ub.jepa.2020.004.01.4.

[28] Marzuki A, Hay I. Towards a Public Participation Framework in Tourism Planning. Tourism Planning and Development. 2013; 10(4): 494-512.

[29] Rasid A, Mustafa MZ, Suradin A, Hassan R. Community Capacity Building for Sustainable Tourism Development: Experience from Miso Walai Homestay. Bus. Manag. 2012; 2(5): 10-19.

[30] Nugroho I, Negara PD. The Role of Leadership and Innovation in Ecotourism Services Activity in Candirejo Village, Borobudur, Central Java, Indonesia. World Acad. Sci. Eng. Technol. 2014; 0079: 1178-1182.

[31] Rogerson JM. Tourism business responses to South Africa's covid-19 pandemic emergency. Geoj. Tour. Geosites. 2021; 35(2): 338-347.

[32] Woelfert FS, Kunst JR. How Political and Social Trust Can Impact Social Distancing Practices During COVID-19 in Unexpected Ways. Front. Psychol. 2020; 11.

[33] Nugroho I, Paramita N, Mengistie BT, Krupskyi OP. Higher education leadership and uncertainty during the COVID-19 pandemic. J. Socioecon. 2021; 4(1): 1-7.

[34] Holman MR, Farris EM, Sumner JL. Local Political Institutions and First-Mover Policy Responses to COVID-19. J. Polit. Institutions Polit. Econ. 2020; 1(4): 523-541.

[35] Nugroho I, Hanafie R, Negara PD, Sudiyono, Yuniar HR. Social Capital and Social Capacity in Rural Ecotourism Development. Indones. J. Geogr. 2021; 53 (1): 153-164.

[36] Cheng M, Wong IKA, Wearing S, McDonald M. Ecotourism social media initiatives in China. J. Sustain. Tour., 2017; 25(3):416-432.

[37] Ramadania R, Al Fatih Y, Darma DC, Fauziah F. Millennials and traveling to domestic destination. Geoj. Tour. Geosites. 2021; 35(2); 398-405.

[38] Leung D, Law R, Hoof VH, Buhalis D. Social Media in Tourism and Hospitality: A Literature Review. J. Travel Tour. Mark. 2013; 30(1-2): 3-22.

[39] Kim Y, Son Y. The role of tourist behaviour in the determination of tourist attractions: Emerging tourist destinations in Jeju Island, South Korea through self-wedding photography. Int. Rev. Spat. Plan. Sustain. 2018; 6(4);62-75.

[40] Peake S, Innes P, Dyer P. Ecotourism and conservation: Factors influencing effective conservation messages. J. Sustain. Tour. 2009; 17(1): 107-127. 